\title{
Postoperative outcome after coronary artery bypass grafting in chronic obstructive pulmonary disease
}

\author{
Hélène Manganas MD, Yves Lacasse MD MSc, Stéphanie Bourgeois MD, Jean Perron MD, \\ François Dagenais MD, François Maltais MD
}

H Manganas, Y Lacasse, S Bourgeois, J Perron, F Dagenais, F Maltais. Postoperative outcome after coronary artery bypass grafting in chronic obstructive pulmonary disease. Can Respir J 2007;14(1):19-24.

BACKGROUND: It is uncertain if the presence and severity of airflow obstruction in chronic obstructive pulmonary disease (COPD) is predictive of surgical morbidity and mortality after coronary artery bypass grafting (CABG).

METHODS: Retrospective study of patients who underwent CABG between 1998 and 2003 in a university-affiliated hospital for whom a preoperative spirometry was available. COPD was diagnosed in smokers or ex-smokers 50 years of age or older in the presence of irreversible airflow obstruction. Patients were divided into three groups depending on the spirometry: controls (forced expiratory volume in $1 \mathrm{~s}\left[\mathrm{FEV}_{1}\right] 80 \%$ or more, $\mathrm{FEV}_{1} /$ forced vital capacity [FVC] greater than 0.7$)$, mild to moderate COPD $\left(\mathrm{FEV}_{1} 50 \%\right.$ or more and $\mathrm{FEV}_{1} / \mathrm{FVC} 0.7$ or less) and severe COPD ( $\mathrm{FEV}_{1}$ less than $50 \%$ and $\mathrm{FEV}_{1} / \mathrm{FVC} 0.7$ or less).

RESULTS: Among the 411 files studied, 322 (249 men, $68 \pm 8$ years of age) were retained (controls, $n=101$; mild to moderate COPD, $n=153$; severe COPD, $\mathrm{n}=68)$. The mortality rate $(3.0 \%, 2.6 \%$ and $0 \%$, respectively) was comparable among the three groups. Patients with severe COPD had a slightly longer hospital stay than controls (mean difference $0.7 \pm 1.4$ days, $\mathrm{P}<0.05$ ). Pulmonary infections were more frequent in severe COPD $(26.5 \%)$ compared with mild to moderate COPD (12.4\%) and controls (12.9\%), $\mathrm{P}<0.05$. Atrial fibrillation tended to be more frequent in severe COPD than in the other two groups.

CONCLUSION: Mortality rate associated with CABG surgery is not influenced by the presence and severity of airflow obstruction in patients with COPD. The incidence of pulmonary infections and length of hospital stay were increased in patients with severe COPD.

Key Words: COPD; Coronary artery bypass; Heart surgery; Postoperative complications

Chronic obstructive pulmonary disease (COPD) is often Considered as a risk factor for postoperative morbidity and mortality after coronary artery bypass grafting (CABG). This is based on previous studies showing an association between a diagnosis of COPD or a low forced expiratory volume in $1 \mathrm{~s}\left(\mathrm{FEV}_{1}\right)$ and post-CABG mortality and morbidity (1-6). However, in the past decade, surgical and anesthesia techniques have improved substantially, leading to reduced postoperative complications so that more recent studies have failed to clearly establish a link between

\section{Pontage coronarien et bronchopneumopathie chronique obstructive : résultats postopéra- toires}

CONTEXTE : On ne sait pas vraiment si la présence de gêne respiratoire et son degré de gravité peuvent être des prédicteurs de morbidité et de mortalité opératoires dans les cas de bronchopneumopathie chronique obstructive (BPCO) après un pontage coronarien.

MÉTHODE : Il s'agit d'une étude rétrospective de patients ayant subi un pontage coronarien entre 1998 et 2003 dans un centre hospitalier universitaire, pour lesquels nous disposions de résultats spirométriques préopératoires. Un diagnostic de BPCO a été posé chez des fumeurs et d'anciens fumeurs âgés de 50 ans et plus, qui présentaient une obstruction irréversible des voies respiratoires. Les patients ont été divisés en trois groupes suivant les résultats de la spirométrie : les témoins (volume expiratoire maximal par seconde [VEMS] : $80 \%$ et plus; rapport VEMS/ capacité vitale forcée $[C V F]$ : supérieur à 0,7 ); BPCO légère ou modérée (VEMS : $50 \%$ et plus; rapport VEMS/CVF : égal ou inférieur à 0,7); BPCO grave (VEMS : moins de $50 \%$; rapport VEMS/CVF : égal ou inférieur à 0,7 ).

RÉSULTATS : Sur 411 dossiers examinés, 322 ont été retenus (249 hommes; âge : 68 \pm 8 ans) (témoins : 101; BPCO légère ou modérée 153; BPCO grave : 68). Le taux de mortalité s'est révélé comparable (3,0\%, 2,6 \% et 0 \%) dans les trois groupes. Le séjour à l'hôpital a été un peu plus long chez les patients atteints d'une BPCO grave que chez les témoins (écart moyen : $0,7 \pm 1,4$ jour; $\mathrm{P}<0,05$ ). Plus de patients atteints d'une $\mathrm{BPCO}$ grave $(26,5 \%)$ ont souffert d'une infection pulmonaire que de patients atteints d'une BPCO légère ou modérée $(12,4 \%)$ ou de témoins $(12,9 \%)(\mathrm{P}<0,05)$. Une tendance plus marquée à la fibrillation auriculaire a été observée dans le groupe de BPCO grave que dans les deux autres groupes.

CONCLUSIONS : La présence de gêne respiratoire et son degré de gravité chez les patients atteints d'une BPCO n'ont pas influé sur le taux de mortalité associé au pontage coronarien. Par contre, la fréquence des infections pulmonaires a été plus élevée dans les cas de BPCO grave et le séjour à l'hôpital, plus long.

COPD and increased morbidity and mortality after CABG $(7-10)$. However the current literature is difficult to interpret in regard to the risk associated with CABG in COPD; in many studies, no spirometry is available while in others, the diagnosis of COPD does not meet the current recommendations.

The objective of the present study was therefore to revisit whether the presence and severity of airflow obstruction associated with COPD are predictive of postoperative mortality and morbidity after CABG. 


\section{Study population}

\section{PATIENTS AND METHODS}

The present retrospective study was conducted at Hôpital Laval, a Cardiopulmonary Institute affiliated with Laval University (Sainte-Foy, Quebec). The cardiac surgery database of the institution was searched to screen for patients who had undergone isolated CABG between January 1998 and December 2003, excluding those combined with valve surgery. From this database, 411 patients with a clinical diagnosis of COPD or who had performed a preoperative spirometry were identified. The medical chart of each of these patients was reviewed by one of the investigators. From these 411 patients, 89 patients were excluded (see exclusion criteria below). The remaining 322 patients were studied and divided into three groups: control, mild to moderate COPD and severe COPD. Because of the retrospective nature of the study, which involved collection and analysis of clinical data, no consent was obtained from the patients. The permission to use the clinical data in an anonymous fashion in a scientific report was obtained from the institutional ethics committee.

Patients with an $\mathrm{FEV}_{1} 80 \%$ or greater and $\mathrm{FEV}_{1} /$ forced vital capacity (FVC) greater than 0.7 constituted the control group, irrespective of their smoking history. COPD was defined by the presence of the following criteria: age of 50 years and older; current or past smoking exposure; and spirometric evidence of irreversible airflow obstruction. According to the 2004 American Thoracic Society/European Respiratory Society position paper on the diagnosis and treatment of COPD, patients with COPD were categorized into two groups based of the degree of airflow obstruction: mild to moderate $\mathrm{COPD}$ with an $\mathrm{FEV}_{1} 50 \%$ or more and $\mathrm{FEV}_{1} / \mathrm{FVC} 0.7$ or less, and severe COPD with an $\mathrm{FEV}_{1}$ less than $50 \%$ and $\mathrm{FEV}_{1} / \mathrm{FVC} 0.7$ or less (11).

Patients were excluded if they were younger than 50 years of age, had a history of asthma, a restrictive pattern on spirometry $\left(\mathrm{FEV}_{1}\right.$ less than $80 \%$ and $\mathrm{FEV}_{1} / \mathrm{FVC}$ greater than 0.7$)$, if no spirometry was available or if it was performed more than three months before surgery or was not technically valid (12).

\section{Data collection}

The preoperative patients' characteristics, details related to the surgery and postoperative complications were recorded for each patient. Preoperative data included age, sex, body mass index, smoking history (current/past or never) and comorbid conditions: recent myocardial infarction (less than one month), left ventricular failure (left ejection fraction less than 40\%), diabetes, hypertension, renal failure, peripheral vascular disease, atrial fibrillation and prior CABG or coronary angioplasty. Pulmonary and cardiac medications were also noted. Based on personal characteristics and comorbid conditions, two predictors of perioperative mortality were computed: the Parsonnet score (13) (with a calculated score composed of 35 variables corresponding to a mortality risk that ranges from $0 \%$ to more than 20\%) and the American Society of Anesthesiologists class (14) (from class I to V). Surgical priority was defined as follows: emergent - coronary disease dictating surgery within hours, urgent - cardiac instability requiring in-hospital care until surgery, and elective - patients in stable condition discharged from the hospital after cardiac catheterization, to be readmitted at a later date for surgery (7). The number of grafts per patient, type of graft (internal mammary artery, venous, radial artery), use of cardiopulmonary bypass and its duration were also recorded.

\section{Spirometry}

Spirometries were performed according to previously described guidelines (12). $\mathrm{FEV}_{1}, \mathrm{FVC}$ and $\mathrm{FEV}_{1} / \mathrm{FVC}$ were expressed according to the reference values published by the European Respiratory Society in 1993 (15). All spirometry tracings were reviewed by a medical team composed of two pulmonologists and two pulmonary fellows.

\section{Cardiopulmonary bypass procedure}

After the insertion of a pulmonary artery catheter, general anesthesia was administered with sufentanil, $2 \mu \mathrm{g} / \mathrm{kg}$ to $15 \mu \mathrm{g} / \mathrm{kg}$; midazolam, $1 \mathrm{mg}$ to $3 \mathrm{mg}$; and pancuronium, $0.1 \mathrm{mg} / \mathrm{kg}$. A propofol infusion was also started at the beginning of cardiopulmonary bypass and stopped before extubation. During cardiopulmonary bypass, all patients were heparinized with $9000 \mathrm{U} / \mathrm{m}^{2}$ of body surface plus $5000 \mathrm{U}$ in the cardiopulmonary bypass circuit. They received protamine sulfate at the end of the cardiopulmonary bypass. Cardiopulmonary bypass was initiated with a single double-stage venous cannula and an aortic cannulation. Mild hypothermia was reached passively, and all surgeries were performed using a membrane oxygenator (Terumo, USA). Most patients were extubated within $12 \mathrm{~h}$ postoperatively. Off-pump CABG procedures were conducted with different stabilizers, a device used to minimize the movements of the beating heart while performing the bypass.

\section{Outcomes}

The primary outcome was postoperative mortality at 30 days. Secondary outcomes included the length of hospital stay, length of stay in intensive care unit, prolonged mechanical ventilation (greater than $48 \mathrm{~h}$ ), reintubations, pulmonary infections, pneumothorax, pleural effusions, atrial fibrillation, other arrhythmias, mediastinitis and sternal wound dehiscence. Pulmonary infections included pneumonia and bronchitis. Pneumonia was defined by radiological evidence of new infiltration, consolidation or cavity, and antibiotic use in the presence of one of three following criteria: purulent sputum, positive blood culture or positive bronchial secretion culture. Bronchitis was defined by presence of purulent sputum production and antibiotic use. Pleural effusion was included in the analysis only if requiring drainage during the hospitalization. Arrhythmias other than atrial fibrillation included supraventricular arrhythmias, atrioventricular block requiring pacemaker, ventricular tachycardia, ventricular fibrillation and asystole.

\section{Statistical analysis}

All data were compared among the three groups. Mean and standard deviation were determined for the continuous variables and categorical variables were expressed using the count or percentage of observed events. According to the data, Student's $t$ test or Wilcoxon rank sum test for difference in location was used to analyze continuous variables. Pairwise comparisons based on Tukey's multiple-comparison procedure were performed for the three study groups. Between-group comparisons for postoperative outcomes were adjusted by taking into account preoperative pulmonary consultation as a covariate. Categorical variables were analyzed with the Fisher's exact tests. The results were considered significant if $\mathrm{P} \leq 0.05$.

\section{RESULTS}

Preoperative patient characteristics

The 322 patients were categorized into one of three groups: control $(n=101)$, mild to moderate COPD $(n=153)$ and severe COPD $(n=68)$. Spirometric data for each group are shown in 
TABLE 1

Preoperative patients' characteristics and spirometric data

\begin{tabular}{|c|c|c|c|c|}
\hline & $\begin{array}{l}\text { Control } \\
(n=101)\end{array}$ & $\begin{array}{c}\text { Mild- } \\
\text { moderate } \\
\text { COPD }(n=153)\end{array}$ & $\begin{array}{l}\text { Severe } \\
\text { COPD } \\
(n=68)\end{array}$ & $\mathbf{P}$ \\
\hline $\mathrm{FEV}_{1}(\mathrm{~L})$ & $2.54 \pm 0.56^{a}$ & $1.85 \pm 0.59^{b}$ & $0.98 \pm 0.24^{c}$ & $<0.001$ \\
\hline $\mathrm{FEV}_{1}$ (predicted) & $101.7 \pm 15.5^{\mathrm{a}}$ & $72.4 \pm 18.2^{b}$ & $38.7 \pm 7.7^{c}$ & $<0.001$ \\
\hline FVC (L) & $3.29 \pm 0.71^{a}$ & $3.06 \pm 0.87^{b}$ & $2.07 \pm 0.57^{c}$ & $<0.001$ \\
\hline FVC (predicted) & $103.3 \pm 15.2^{\mathrm{a}}$ & $94.0 \pm 19.7^{\mathrm{b}}$ & $64.2 \pm 14.5^{c}$ & $<0.001$ \\
\hline $\mathrm{FEV}_{1} / \mathrm{FVC}$ & $0.78 \pm 0.05^{a}$ & $0.61 \pm 0.08^{b}$ & $0.49 \pm 0.10^{c}$ & $<0.001$ \\
\hline Age (years) & $67.5 \pm 8.2$ & $67.9 \pm 7.5$ & $68.5 \pm 6.1$ & 0.69 \\
\hline Sex (Male/Female) & $77 / 24$ & $117 / 36$ & $55 / 13$ & 0.76 \\
\hline $\begin{array}{l}\text { Body mass } \\
\text { index }\left(\mathrm{kg} / \mathrm{m}^{2}\right)\end{array}$ & $28.2 \pm 5.0^{a}$ & $27.1 \pm 4.8^{\mathrm{ab}}$ & $25.9 \pm 4.6^{b}$ & 0.049 \\
\hline $\begin{array}{l}\text { Positive smoking } \\
\text { history }\end{array}$ & $77(74)^{a}$ & $146(97)^{\mathrm{b} *}$ & $67(100)^{b}$ & $<0.001$ \\
\hline $\begin{array}{l}\text { Recent myocardial } \\
\text { infarction }\end{array}$ & $28(27.7)$ & $44(28.8)$ & $20(29.4)$ & 0.97 \\
\hline $\begin{array}{l}\text { Left ventricular } \\
\text { failure }\end{array}$ & $16(19.3)$ & $25(17.7)$ & $11(17.5)$ & 0.96 \\
\hline Diabetes & $28(27.7)$ & $35(22.9)$ & $20(29.4)$ & 0.48 \\
\hline Hypertension & $25(24.8)$ & $45(29.4)$ & $24(35.8)$ & 0.30 \\
\hline Renal failure & $4(4.0)^{a}$ & $12(7.8)^{\mathrm{ab}}$ & $10(14.7)^{b}$ & 0.047 \\
\hline $\begin{array}{l}\text { Peripheral vascular } \\
\text { disease }\end{array}$ & $37(36.6)$ & $37(24.2)$ & $16(23.5)$ & 0.07 \\
\hline Atrial fibrillation & $6(5.9)$ & $10(6.5)$ & $5(7.4)$ & 0.92 \\
\hline $\begin{array}{l}\text { Prior CABG or } \\
\text { coronary } \\
\text { angioplasty }\end{array}$ & $13(12.9)$ & $22(14.4)$ & $11(16.2)$ & 0.84 \\
\hline ASA class & $3.2 \pm 0.4$ & $3.3 \pm 0.5$ & $3.3 \pm 0.5$ & 0.10 \\
\hline Parsonnet score & $12.3 \pm 7.5$ & $11.8 \pm 7.8$ & $11.8 \pm 6.9$ & 0.89 \\
\hline
\end{tabular}

*3\% patients with unknown smoking history. Values are number of observations (\%) or mean $\pm S D$. Means with different letters are statistically significant, $P<0.05$. ASA American Society of Anesthesiologists; CABG Coronary artery bypass grafting; COPD Chronic obstructive pulmonary disease; FEV Forced expiration volume in $1 \mathrm{~s}$; FVC Forced vital capacity

Table 1. The three groups were comparable for most of the demographic data (Table 1). Patients in the control group had higher body mass index values compared with patients in the severe COPD group. The three groups were comparable according to the number of comorbid conditions except for renal failure, which was more prevalent in the severe COPD group. The Parsonnet score and the American Society of Anesthesiologists class were similar in all groups.

Table 2 shows cardiac and pulmonary medication used by the patients of the three groups. No statistically significant differences were found for all the cardiac medications among the three groups, even for the use of beta-blockers which were used by $41.6 \%, 41.8 \%$ and $35.3 \%$ in control, mild to moderate $\mathrm{COPD}$ and severe COPD groups, respectively; $\mathrm{P}=0.65$. Fifteen per cent, $30 \%$ and $41 \%$ of patients were seen preoperatively by a respirologist in the control, mild to moderate COPD and severe COPD groups, respectively.

\section{Surgical procedures}

Nine experienced surgeons contributed to the present study, each of them performing over 250 heart surgeries per year. Cardiopulmonary bypass was used in a similar proportion of patients in the three groups (greater than 90\%) (Table 3). There was no difference in the duration of cardiopulmonary bypass and number of grafts among the three groups. Internal
TABLE 2

Preoperative pulmonary and cardiac medication

\begin{tabular}{|c|c|c|c|c|}
\hline & $\begin{array}{l}\text { Control } \\
(n=101)\end{array}$ & $\begin{array}{c}\text { Mild- } \\
\text { moderate } \\
\text { COPD }(n=153)\end{array}$ & $\begin{array}{c}\text { Severe } \\
\text { COPD } \\
(n=68)\end{array}$ & $\mathbf{P}$ \\
\hline \multicolumn{5}{|l|}{ Pulmonary } \\
\hline $\begin{array}{r}\text { Short-acting } \\
\beta 2 \text {-agonist }\end{array}$ & $31(30.7)^{\mathrm{a}}$ & $83(54.3)^{\mathrm{b}} \quad 5$ & $57(83.8)^{c}$ & $<0.001$ \\
\hline $\begin{array}{l}\text { Long-acting } \\
\beta 2 \text {-agonist }\end{array}$ & $7(6.9)^{a}$ & $15(9.8)^{a}$ & $18(26.5)^{b}$ & $<0.001$ \\
\hline Ipratropium & $9(8.9)^{a}$ & $40(26.1)^{\mathrm{b}} \quad 3$ & $38(55.9)^{c}$ & $<0.001$ \\
\hline Tiotropium & $0(0.0)^{a}$ & $3(5.1)^{\mathrm{ab}}$ & $3(11.5)^{b}$ & 0.045 \\
\hline Inhaled corticosteroid & $29(28.7)^{a}$ & $70(45.8)^{\mathrm{b}} \quad 5$ & $52(76.5)^{c}$ & $<0.001$ \\
\hline Oral corticosteroid & $1(1.0)^{a}$ & $6(3.9)^{a}$ & $11(16.2)^{b}$ & $<0.001$ \\
\hline Theophylline & $0(0.0)^{a}$ & $8(5.2)^{\mathrm{ab}}$ & $8(11.8)^{b}$ & $<0.001$ \\
\hline \multicolumn{5}{|l|}{ Cardiac } \\
\hline beta-blockers & $42(41.6)$ & $64(41.8)$ & $24(35.3)$ & 0.65 \\
\hline \multicolumn{5}{|l|}{ Calcium channel } \\
\hline blockers & $70(69.3)$ & $103(67.3)$ & $48(70.6)$ & 0.90 \\
\hline \multicolumn{5}{|l|}{ ACE inhibitors/AT II } \\
\hline receptor blockers & $49(48.5)$ & $80(52.3)$ & $34(50.0)$ & 0.83 \\
\hline Digoxin & $7(6.9)$ & $11(8.7)$ & $4(7.7)$ & 0.96 \\
\hline Amiodarone & $8(7.9)$ & $4(3.2)$ & $3(6.0)$ & 0.24 \\
\hline Diuretics & $36(35.6)$ & $51(33.3)$ & $18(26.5)$ & 0.45 \\
\hline Nitrates & $64(63.4)$ & 107 (69.9) & $40(58.8)$ & 0.23 \\
\hline Acetylsalicylic acid & $68(67.3)$ & $94(61.4)$ & $38(55.9)$ & 0.32 \\
\hline Hypolipemic agents & $67(66.3)$ & $93(60.8)$ & $37(54.4)$ & 0.29 \\
\hline
\end{tabular}

Values are number of observations (\%) or mean $\pm S D$. Means with different letters are statistically significant, $P<0.05$. ACE Angiotensin-converting enzyme; AT II Angiotensin II; COPD Chronic obstructive pulmonary disease

mammary artery grafting was used less frequently in COPD patients. The proportions of emergent/urgent and elective surgeries were comparable among the three groups.

\section{Postoperative events}

Among the 322 patients included in study, there were seven deaths: three in the control group and four in mild to moderate COPD group (Table 4). The causes of death included cardiogenic shock $(n=2)$, perioperative myocardial infarction $(n=1)$, severe arrhythmia $(n=1)$, multiorgan dysfunction syndrome $(n=1)$, pulmonary embolism $(n=1)$ and cerebrovascular accident $(\mathrm{n}=1)$. Hospital stay was slightly longer in both COPD groups, although this difference reached statistical significance only for the comparison between controls and severe COPD (Table 4). Length of stay in the intensive care unit and the proportion of patients requiring prolonged mechanical ventilation or reintubation were similar in the three groups.

Pneumonia was more frequent in patients with COPD than in the control group, whereas the incidence of bronchitis was only increased in the severe COPD group (Table 4). Other pulmonary complications, including pneumothorax and pleural effusions, were found in a similar proportion of patients in the three groups. Atrial fibrillation tended to occur more frequently in severe COPD patients, although the difference was not statistically significant $(35.6 \%, 30.1 \%$ and $45.6 \%$ in control, mild to moderate COPD and severe COPD groups, respectively, $\mathrm{P}=0.08$ ). Other arrhythmias, mediastinitis and sternal wound dehiscence had comparable incidence in the three groups. Adjusting the between-group comparisons for the different postoperative outcomes taking into 
TABLE 3

Surgical characteristics

\begin{tabular}{|c|c|c|c|c|}
\hline & $\begin{array}{l}\text { Control } \\
(n=101)\end{array}$ & $\begin{array}{c}\text { Mild- } \\
\text { moderate } \\
\text { COPD }(n=153)\end{array}$ & $\begin{array}{l}\text { Severe } \\
\text { COPD } \\
(n=68)\end{array}$ & $\mathbf{P}$ \\
\hline CBP & $95(94.1)$ & $142(93.4)$ & $62(91.2)$ & 0.77 \\
\hline CBP duration (min) & $80.2 \pm 27.9$ & $78.1 \pm 25.0$ & $74.3 \pm 25.6$ & 0.37 \\
\hline Number of grafts & $3.6 \pm 1.0$ & $3.4 \pm 0.9$ & $3.5 \pm 1.1$ & 0.50 \\
\hline $\begin{array}{l}\text { Mammary artery } \\
\text { graft }\end{array}$ & \multicolumn{3}{|c|}{ Mammary artery } & 0.02 \\
\hline \multicolumn{5}{|c|}{ Surgical priority (emergent- } \\
\hline urgent/elective) & $21 / 80$ & $24 / 129$ & $10 / 58$ & 0.50 \\
\hline
\end{tabular}

Values are number of observations (\%) or mean $\pm S D$. Means with different letters are statistically significant, $P<0.05$. CBP Cardiopulmonary bypass; COPD Chronic obstructive pulmonary disease

account pulmonary consultation as a covariate did not modify the results.

\section{DISCUSSION}

In the present study, we found that patients with severe COPD can undergo $\mathrm{CABG}$ without increased mortality risk when compared with patients with normal pulmonary function or with mild to moderate COPD. The postoperative outcome in patients with severe airflow obstruction was similar to those with either normal lung function or mild to moderate COPD with the exception of an increased risk of pulmonary infections, a tendency to postoperative atrial fibrillation and a slightly increased length of hospital stay.

These findings are at variance to those previously reported in some studies (1-6). In their study, Grover et al (1) found that an $\mathrm{FEV}_{1}$ less than $1.25 \mathrm{~L}$ was associated with an increased post-CABG mortality (11.7\% versus $3.8 \%$ in patients with an $\mathrm{FEV}_{1}$ greater than $1.25 \mathrm{~L}$ ). Although these patients had low $\mathrm{FEV}_{1}$, the type of spirometric abnormalities (obstructive versus restrictive) was not specified. The same authors also reported that a clinical diagnosis of COPD (irrespectively of the FEV value) was associated with an increased postoperative mortality (6.4\% versus $4.3 \%)$. Kurki et al (5) found an association between a diagnosis of COPD or any pulmonary disorder with an $\mathrm{FEV}_{1} 50 \%$ or less and postoperative morbidity after CABG. Postoperative morbidity end points included various complications such as neurological events, arrhythmia, pulmonary infections, wound infections, renal failure, cardiogenic shock and even death. Other studies have also associated COPD with an adverse post-CABG outcome $(2,3,6)$. However, in these studies, no spirometric data were reported and the postoperative mortality rate for COPD patients was very high, reaching up to $33.3 \%$ in some studies. Conversely, more recent studies $(7-10)$ failed to identify mild to moderate COPD as a risk factor of postoperative mortality and morbidity.

In this regard, our study may help in clarifying these discrepant findings. First, all patients had a preoperative spirometry and they were classified based on the degree of airflow obstruction. In addition, patients with reduced $\mathrm{FEV}_{1}$ due to restrictive disorder were excluded. Finally, surgeries were performed in a more recent period than previous studies, with improved anesthesia and surgical techniques and postoperative pulmonary care. This could explain the favourable postoperative outcome of our patients, even in the presence of severe
TABLE 4

Postoperative mortality and morbidity

\begin{tabular}{lcccc}
\hline & $\begin{array}{c}\text { Control } \\
(\mathbf{n = 1 0 1 )}\end{array}$ & $\begin{array}{c}\text { Mild- } \\
\text { moderate } \\
\text { COPD }(\mathbf{n = 1 5 3})\end{array}$ & $\begin{array}{c}\text { Severe } \\
\text { COPD } \\
(\mathbf{n = 6 8 )}\end{array}$ & $\mathbf{P}$ \\
\hline Mortality & $3(3.0)$ & $4(2.6)$ & $0(0.0)$ & 0.48 \\
$\begin{array}{l}\text { Days of hospitalization } \\
\quad \text { days) }\end{array}$ & $10.6 \pm 8.7^{\mathrm{a}}$ & $11.3 \pm 10.2^{\mathrm{ab}}$ & $11.3 \pm 6.0^{\mathrm{b}}$ & 0.02 \\
LICU (days) & $2.4 \pm 1.7$ & $2.7 \pm 3.4$ & $2.5 \pm 1.7$ & 0.68 \\
Prolonged mechanical & & & & \\
$\quad$ ventilation & $6(5.9)$ & $4(2.6)$ & $2(3.0)$ & 0.37 \\
Reintubation & $3(3.0)$ & $5(3.3)$ & $3(4.6)$ & 0.85 \\
Bronchitis & $13(13)^{\mathrm{a}}$ & $13(8.5)^{\mathrm{a}}$ & $16(23.5)^{\mathrm{b}}$ & 0.01 \\
Pneumonia & $0(0)^{\mathrm{a}}$ & $8(5.2)^{\mathrm{b}}$ & $2(2.9)^{\mathrm{b}}$ & 0.04 \\
Pneumothorax & $4(4.0)$ & $13(8.5)$ & $3(4.4)$ & 0.33 \\
Pleural effusion & $1(1.0)$ & $9(5.9)$ & $3(4.4)$ & 0.15 \\
Atrial fibrillation & $36(35.6)$ & $46(30.1)$ & $31(45.6)$ & 0.08 \\
Other arryhthmia & $13(12.9)$ & $13(8.5)$ & $11(16.4)$ & 0.20 \\
Mediastinitis & $2(2.0)$ & $1(0.7)$ & $1(1.5)$ & 0.55 \\
Sternal wound & & & & \\
$\quad$ dehiscence & $2(2.0)$ & $1(0.7)$ & $1(1.5)$ & 0.55 \\
\hline
\end{tabular}

Values are number of observations (\%) or mean $\pm S D$. Means with different letters are statistically significant, $P<0.05$. COPD Chronic obstructive pulmonary disease; LICU Length of stay in intensive care unit

airflow obstruction. Our results are consistent with postoperative mortality rates reported in recent studies (16-18).

Many physiological and biochemical changes could contribute to pulmonary dysfunction after cardiac surgery (19-21). Cardiopulmonary bypass use, internal mammary artery grafting and general anesthesia are some factors that can alter lung mechanics and gas exchange, and induce lung injury by stimulating production of various proinflammatory mediators (21). Some studies identified COPD as a risk factor for prolonged mechanical ventilation (22) or postoperative pneumonia (23). In the present study, an increased risk of postoperative pulmonary infections in patients with severe COPD was found. The number of patients necessitating prolonged mechanical ventilation or showing other pulmonary complications was comparable among the three groups. It is important to note that patients in both COPD groups had fewer artery mammary grafts compared to those belonging to the control group, a potential bias in favour of reducing pulmonary complications in COPD (21). The deleterious effects induced by cardiopulmonary bypass on pulmonary mechanics could be reduced by the use of less invasive heart surgery such as beating heart surgery and minimally invasive direct CABG (24,25). Whether increasing use of these novel techniques will further improve postoperative outcome in COPD is unknown.

Patients in the severe COPD group had an important alteration in their pulmonary function, with a mean $\mathrm{FEV}_{1}$ less than $1 \mathrm{~L}$. One potential explanation for the low occurrence of postoperative morbidities in these individuals is that they may have been selected in a more restrictive way during their preoperative evaluation compared with patients with less pulmonary impairment. The number of comorbid conditions, the Parsonnet score and the American Society of Anesthesiologists class were similar in the three groups suggesting that the health status was similar in patients with severe COPD compared with the other groups. It would have been interesting to study the postoperative outcome of very severe COPD. Twenty-five patients with an $\mathrm{FEV}_{1}$ less than 35\% 
were included in the present study. Postoperative mortality and morbidity was similar compared to patients with an $\mathrm{FEV}_{1}$ between $35 \%$ and $50 \%$ predicted. It should be noted that no patients had an $\mathrm{FEV}_{1}$ less than $20 \%$ or were on long-term oxygen therapy. Thus, we cannot comment on the operative risk in these individuals.

Another interesting finding of our study is the high prevalence of postoperative atrial fibrillation in the three groups, up to $45.6 \%$ in severe COPD. This may be due to high prevalence of other well-established risk factors including advanced age (more than $50 \%$ of studied population were older than 70 years of age), cardiopulmonary bypass use and beta-blocker withdrawal. Whether factors such as electrolyte imbalance, right atrial manipulation and atrial myocardial ischemia (26) could have played a role was not evaluated in the present study. There was a trend toward more frequent postoperative atrial fibrillation in patients with severe compared with mild to moderate COPD. Although it did not reach statistical significance, this trend is consistent with studies that identified COPD as a significant risk factor for this specific arrhythmia $(26,27)$.

In the present investigation, the overall rate of postoperative sternal dehiscences $(1.2 \%)$ and mediastinitis (1.2\%) was similar to the reported incidence of these complications $(28,29)$. Although COPD has been proposed as a risk factor for these complications $(28,29)$, the rate of sternal dehiscences and mediastinitis were not increased in patients with COPD in our study. One possible explanation is that less frequent use of mammary artery grafting in COPD may have promoted sternal healing by reducing the occurrence of sternal ischemia. However, caution is warranted in the interpretation of these findings given the small number of sternal dehiscences $(n=4)$ and mediastinitis $(n=4)$ in our patients.

Because a valid spirometric tracing was a requirement to be included in the study, and because spirometry is not routinely performed preoperatively, patients involved in the present investigation represent only a subset of all patients undergoing a CABG in our institution. Accordingly, there could be a bias toward the selection of more symptomatic patients in whom a greater rate of postoperative complications could also be expected. However, the impact of this potential bias is likely to be small because the postoperative mortality and morbidity in this cohort of patients is similar to what is reported in the cardiac surgery literature (16-18). On the other hand, in some patients, the diagnosis of COPD was probably made at the time of the surgery as suggested by the considerable portion of patients with unequivocal spirometric evidence of COPD who did not receive any pharmacological treatment for this condition. This observation is consistent with a previous epidemiological study (30) and with the notion that COPD is under-recognized and undertreated. These potential selection biases should not detract from the usefulness of the present investigation. In fact, this study represents a real life situation where clinicians are confronted with the results of a spirometry in the preoperative evaluation of a patient undergoing a CABG. Pneumonia and bronchitis were defined according to standard clinical criteria. We acknowledge the limitation of these definitions, particularly in a postoperative context where the differential diagnosis of new lung infiltrates is vast. Only clinical episodes for which clinicians thought that a specific treatment with antibiotics was necessary were taken into account into the analysis. This was done in an attempt to minimize the number of false-positive episodes of respiratory tract infections in this retrospective analysis.
In conclusion, the current study shows that the presence and worsening of airflow obstruction are not associated with greater risk of mortality following CABG surgery in COPD compared with patients with normal spirometric function. Severe COPD patients when compared with mild to moderate COPD patients and patients with normal spirometry had a similar postoperative outcome with the exception of more frequent pulmonary infections, a trend toward more frequent atrial fibrillation and a slightly longer hospital stay. Coronary revascularization surgery appears to be a safe procedure in COPD.

ACKNOWLEDGEMENTS: The authors acknowledge the help of Brigitte Dionne and Brigitte Jean for the data collection and of Serge Simard for the statistical analyses.

\section{REFERENCES}

1. Grover FL, Hammermeister KE, Burchfiel C. Initial report of the Veterans Administration Preoperative Risk Assessment Study for Cardiac Surgery. Ann Thorac Surg 1990;50:12-26.

2. Higgins TL, Estafanous FG, Loop FD, Beck GJ, Blum JM, Paranandi L. Stratification of morbidity and mortality outcome by preoperative risk factors in coronary artery bypass patients. A clinical severity score. JAMA 1992;267:2344-8.

3. Grover FL, Johnson RR, Marshall G, Hammermeister KE. Factors predictive of operative mortality among coronary artery bypass subsets. Ann Thorac Surg 1993;56:1296-306.

4. Durand M, Combes P, Eisele JH, Contet A, Blin D, Girardet P. Pulmonary function tests predict outcome after cardiac surgery. Acta Anaesthesiol Belg 1993;44:17-23.

5. Kurki TS, Kataja M. Preoperative prediction of postoperative morbidity in coronary artery bypass grafting. Ann Thorac Surg 1996;61:1740-5.

6. Samuels LE, Kaufman MS, Morris RJ, Promisloff R, Brockman SK. Coronary artery bypass grafting in patients with COPD. Chest 1998;113:878-82.

7. Spivack SD, Shinozaki T, Albertini JJ, Deane R. Preoperative prediction of postoperative respiratory outcome. Coronary artery bypass grafting. Chest 1996;109:1222-30.

8. Jacob B, Amoateng-Adjepong Y, Rasakulasuriar S, Manthous CA, Haddad R. Preoperative pulmonary function tests do not predict outcome after coronary artery bypass. Conn Med 1997;61:327-32.

9. Bando K, Sun K, Binford RS, Sharp TG. Determinants of longer duration of endotracheal intubation after adult cardiac operations. Ann Thorac Surg 1997;63:1026-33.

10. Michalopoulos A, Geroulanos S, Papadimitriou L, et al. Mild or moderate chronic obstructive pulmonary disease risk in elective coronary artery bypass grafting surgery. World J Surg 2001;25:1507-11.

11. Celli BR, MacNee W, ATS/ERS Task Force. Standards for the diagnosis and treatment of patients with COPD: A summary of the ATS/ERS position paper. Eur Respir J 2004;23:932-46.

12. American Thoracic Society. Standardization of Sprirometry, 1994 Update. Am J Respir Crit Care Med 1995;152:1107-36.

13. Parsonnet V, Dean D, Bernstein AD. A method of uniform stratification of risk for evaluating the results of surgery in acquired adult heart disease. Circulation 1989;79:13-12.

14. Dripps RD, Lamont A, Eckenhoff JE. The role of anesthesia in surgical mortality. JAMA 1961;178:261-6.

15. Quanjer PH, Tammeling GJ, Cotes JE, Pedersen OF, Peslin R, Yernault JC. Lung volumes and forced ventilatory flows. Report Working Party Standardization of Lung Function Tests, European Community for Steel and Coal. Official Statement of the European Respiratory Society. Eur Respir J Suppl 1993;16:5-40.

16. Birkmeyer JD, Siewers AE, Finlayson EV, et al. Hospital volume and surgical mortality in the United States. N Engl J Med 2002;346:1128-37.

17. Peterson ED, Coombs LP, DeLong ER, Haan CK, Ferguson TB. Procedural volume as a marker of quality for CABG surgery. JAMA 2004;291:195-201.

18. Nilsson J, Algotsson L, Hoglund P, Lugrs C, Brandt J. Early mortality in coronary bypass surgery: The EuroSCORE versus The Society of Thoracic Surgeons risk algorithm. Ann Thorac Surg 2004;77:1235-9. 
19. Bonacchi M, Prifti E, Giunti G, Salica A, Frati G, Sani G. Respiratory dysfunction after coronary artery bypass grafting employing bilateral internal mammary arteries: The influence of intact pleura. Eur J Cardiothorac Surg 2001;19:827-33.

20. Ishikawa S, Takahashi T, Ohtaki A, et al. Peripheral pulmonary atelectasis and oxygentation impairment following coronary artery bypass grafting. J Cardiovasc Surg (Torino) 2002;43:419-22.

21. Ng CS, Wan S, Yim AP, Arifi AA. Pulmonary dysfunction after cardiac surgery. Chest 2002;121:1269-77.

22. Légaré JF, Hirsch GM, Buth KJ, MacDougall C, Sullivan JA. Preoperative prediction of prolonged mechanical ventilation following coronary artery bypass grafting. Eur J Cardiothorac Surg 2001;20:930-6.

23. Gaynes R, Bizek B, Mowry-Hanley J, Kirsh M. Risk factors for nosocomial pneumonia after coronary artery bypass graft operations. Ann Thorac Surg 1991;51:215-8.

24. Covino E, Santise G, Di Lello F, et al. Surgical myocardial revascularization $(\mathrm{CABG})$ in patients with pulmonary disease: Beating heart versus cardiopulmonary bypass. J Cardiovasc Surg (Torino) 2001;42:23-6
25. Güler M, Kirali K, Toker ME, et al. Different CABG methods in patients with chronic obstructive pulmonary disease. Ann Thorac Surg 2001;71:152-7.

26. Ad N, Snir E, Vidne BA, Golomb E. Potential preoperative markers for the risk of developing atrial fibrillation after cardiac surgery. Semin Thorac Cardiovasc Surg 1999;11:308-13.

27. Kuralay E, Cingoz F, Kilic S, et al. Supraventricular tachyarrythmia prophylaxis after coronary artery surgery in chronic obstructive pulmonary disease patients (early amiodarone prophylaxis trial). Eur J Cardiothorac Surg 2004;25:224-30.

28. Braxton JH, Marrin CA, McGrath PD, et al. Mediastinitis and long-term survival after coronary artery bypass graft surgery. Ann Thorac Surg 2000;70:2004-7.

29. Gårdlund B, Bitkover CY, Vaage J. Postoperative mediastinitis in cardiac surgery - microbiology and pathogenesis. Eur J Cardiothorac Surg 2002;21:825-30.

30. Sin DD, Man SF. Why are patients with chronic obstructive pulmonary disease at increased risk of cardiovascular diseases? The potential role of systemic inflammation in chronic obstructive pulmonary disease. Circulation 2003;107:1514-9. 


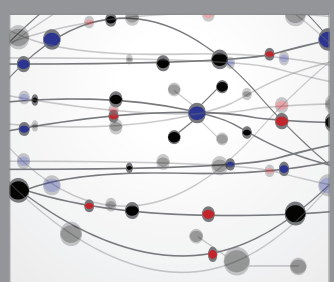

The Scientific World Journal
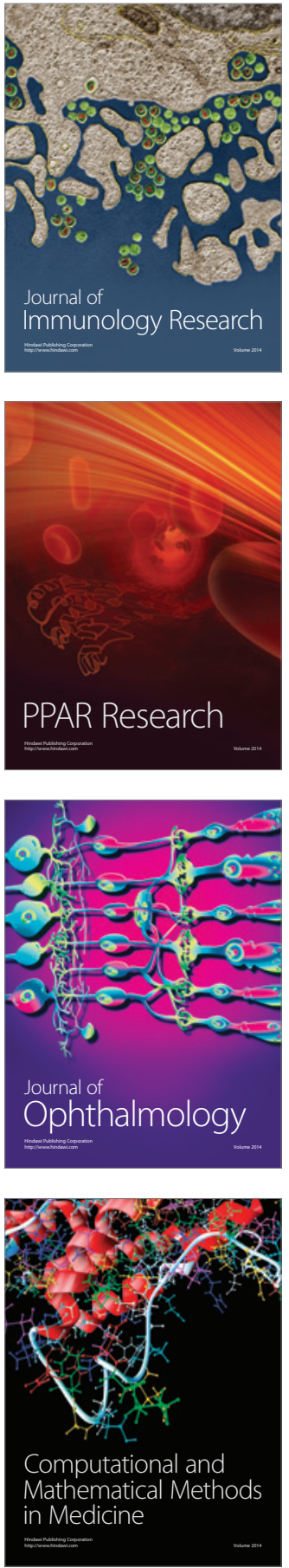

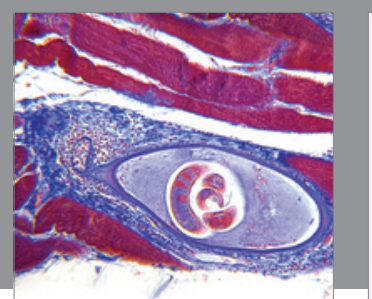

Gastroenterology Research and Practice

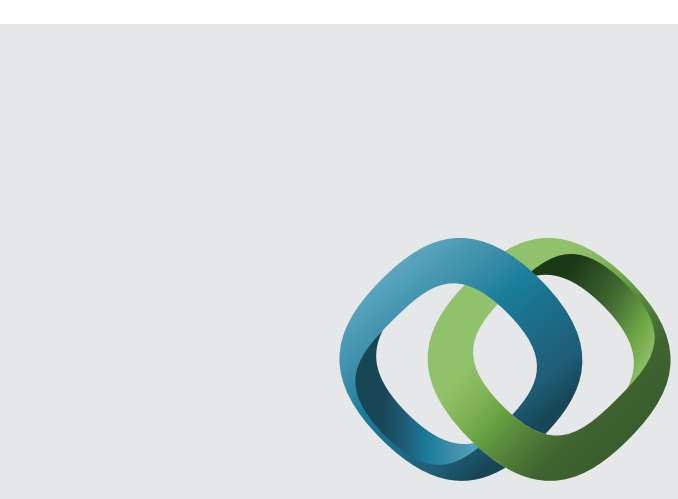

\section{Hindawi}

Submit your manuscripts at

http://www.hindawi.com
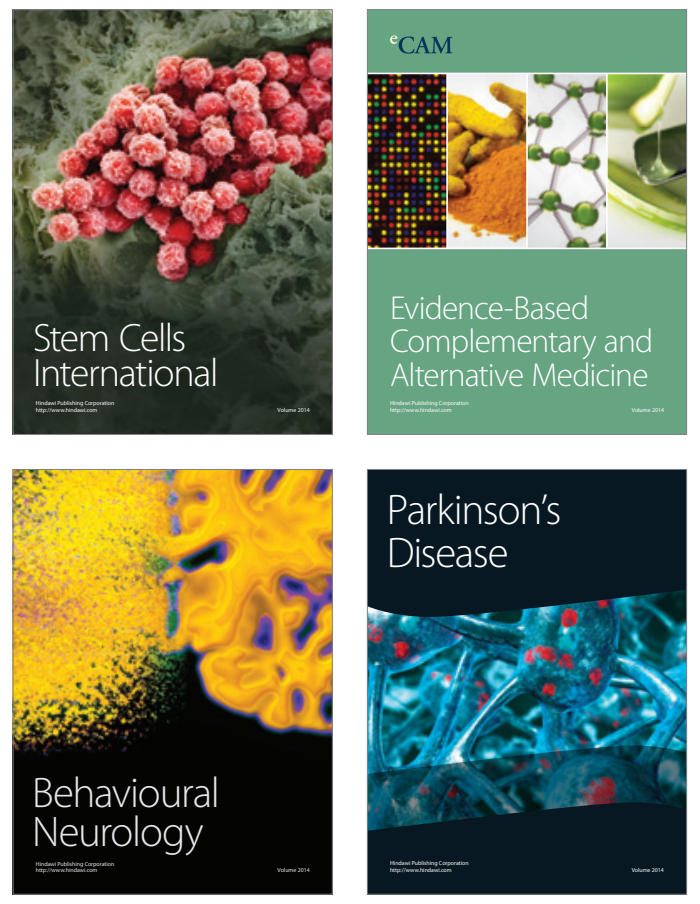
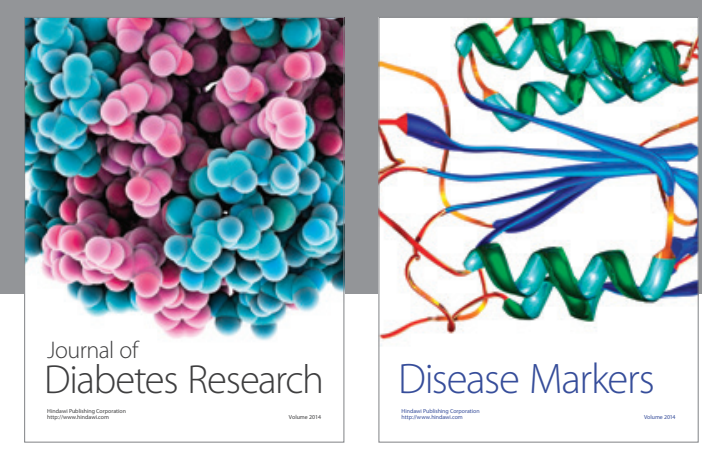

Disease Markers
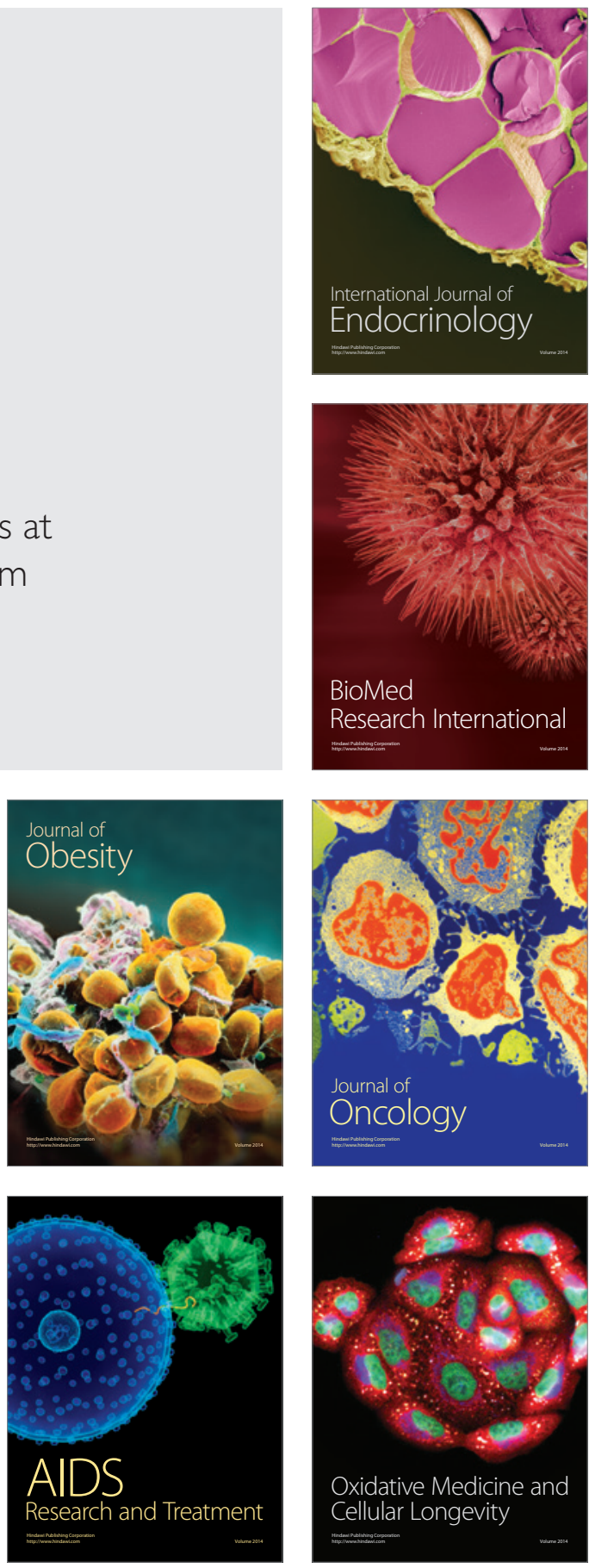